\title{
Extra-buccal surgical access for canine removal included in mandibular symphysis: case report
}

\author{
Acesso cirúrgico extra-bucal para remoção de canino \\ incluso em sinfise mandibular: relato de caso
}

\author{
Lucas Augusto Pereira SOUTO1 ID https://orcid.org/0000-0003-1981-4314 \\ Daniela MENESES-SANTOS1 iD https://orcid.org/0000-0002-8898-9508 \\ Cristovão Marcondes de Castro RODRIGUES ${ }^{1}$ iD https://orcid.org/0000-0002-0590-9075 \\ Claúdia Jordão SILVA' iD https://orcid.org/0000-0002-7114-4859 \\ Flaviana Soares ROCHA ${ }^{1}$ iD https://orcid.org/0000-0002-6759-2229
}

Marcelo Caetano Parreira da SILVA1 iD https://orcid.org/0000-0001-6010-8062

\begin{abstract}
Included teeth are all the dental elements that arrive the normal time of its eruption, remains immersed within the tissues. Usually found when missing a tooth, or on routine radiographic examinations. In the presence of included teeth, it is necessary to define the best treatment approach, whether it is surgical, through exodontia, or by orthodontic tracings. Inclusive canines, in the symphysis region and near the base of the mandible, are rare and make the use of orthodontic traction techniques contraindicated. Presence of teeth in the intraosseous ectopic position can cause injuries, such as alveolodentary ankylosis, calcium metamorphosis of the pulp and aseptic pulp necrosis, among others. Anamnesis, physical examination (intra- and extraoral) and radiographic examinations such as panoramic, periapical, computed tomography, and occlusal radiographs should be performed to make the diagnosis adequate. In general, the success of the treatment depends on the age of the patient and the position of the canines at the time of the surgical procedure. The objective of this work is the extraction of a lower canine with extra-oral access in an outpatient clinical setting under local anesthesia.
\end{abstract}

Indexing terms: Cuspid. Ambulatory surgical procedures. Anesthesia, local.

\section{RESUMO}

Dentes inclusos são todos os elementos dentários que chegada a época normal de seu irrompimento, permanece imerso no interior dos tecidos. Geralmente encontrados quando se observa ausência de algum dente, ou em exames radiográficos de rotina. Na presença de dentes inclusos, deve-se definir qual a melhor abordagem de tratamento, se é cirúrgica, através de exodontias, ou por tracionamentos ortodônticos. Caninos inclusos, em região de sínfise e próximos à base da mandíbula, são raros e fazem com que o uso de técnicas do tipo tracionamento ortodôntico sejam contra-indicadas. Presença de dentes em posição ectópica intraósseos podem causar injúrias,

$\checkmark \nabla v$

1 Universidade Federal de Uberlândia, Faculdade de Odontologia, Departamento de Cirurgia e Traumatologia Bucomaxilofacial e Implantodontia. Av. Pará, 1748, Umuarama, 38405-320, Uberlândia, MG, Brasil. Correspondence to: D Meneses-Santos. E-mail: <danyymeneses@yahoo.com.br>.

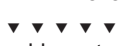

Souto LAP, Meneses-Santos D, Rodrigues CMC, Silva CJ, Rocha FS, Silva MCP. Extra-buccal approach of transmigrated canine. RGO, Rev Gaúch Odontol. 2020;68: e20200053. http://dx.doi.org/10.1590/1981-863720200005320190031 
como anquilose alveolodentária, metamorfose cálcica da polpa e necrose pulpar asséptica, dentre outros. Para que o diagnóstico seja adequado, deve-se realizar, anamnese, exame físico (intra e extraoral) e exames radiográficos como panorâmicas, periapicais, tomografias computadorizadas e radiografias oclusais. Em geral, o sucesso do tratamento depende da idade do paciente e da posição dos caninos no momento do procedimento cirúrgico. O objetivo deste trabalho relata a extração de um canino inferior com acesso extra-oral em ambiente clínico ambulatorial sob anestesia local.

Termos de indexação: Dente canino. Procedimentos cirúrgicos ambulatórios. Anestesia local.

\section{INTRODUCTION}

Transmigration is the pre-eruptive intraosseous migration of a tooth, crossing the mandibular midline [1]. In other words, transmigration refers to instances where the lower canine is outside its usual location, especially near the midline [2]. The canines included in the mentonian region are less discussed in the literature, are rare, and are of an unknown etiology [3].

Transmigrations are usually asymptomatic and discovered during routine radiographic orthodontic examinations [1]. They may cause neuralgic symptoms [4] and can be reabsorbed by root pressure or inclination of adjacent teeth [5], or migrate to adjacent structures such as the coronoid process [6], causing pain and discomfort to the patient.

The actual distance of canine migration through the mandibular midline is more important than the migration itself [3]. The transmissible canines are classified according to the following criteria: Type 1: Canine positioned mesioangularly through the midline within the mandible bone, labial, or lingual to the anterior teeth, and the part of the crown of the tooth traversing the midline. Type 2: canine horizontally impacted near the lower border of the mandible, below the apex of the incisors. Type 3: Canine eruption mesial or distal to the opposing canine. Type 4 : Canine horizontally impacted near the lower border of the mandible, below the apexes of premolars or molars on the opposite side. Type 5: Canine positioned vertically in the midline (the long axis of the tooth crossing the midline) regardless of the eruption state [7].

Transmigrated canines occur due to environmental, systemic, or local conditions [8], and including a long eruption path of the canine germ, traumatic factors, early loss of deciduous canine teeth, lack of space, abnormal crown length, functional endocrine disorders, hereditary factors, odontomas, and tumors $[4,9]$.

For diagnosis, radiographic examinations and radiographs (including panoramic, occlusal and periapical views) are important [10]. The Clark technique is also used to locate an anatomical repair or any body in the vestibularlingual direction [11].

Herein we report a case of surgical treatment of canine transmigration at the base of the mandibular symphysis by extra-buccal access, under local anesthesia.

\section{CASE REPORT}

Our patient was a 16-year-old female with melanoderma who sought orthodontic treatment for aesthetic rehabilitation. On physical examination, the dental surgeon observed no erupted dental element 43 in the dental arch. The patient was referred to the Department of Buccomaxillofacial Surgery and Traumatology at the Federal University of Uberlândia for evaluation and conduct.

On panoramic radiography (figure 1), the right lower canine was included in the mandibular base, with part of its crown crossing the midline. Lateral teleradiography (figure 2) revealed dental element 43 located within the mandibular base. Given that surgical traction was impossible due to the position of the tooth, surgical removal was selected as treatment. The patient had no systemic comorbidities, allergies, or surgical contraindications.

The patient underwent conscious sedation with oral $7.5 \mathrm{mg}$ Midazolan 1 hour before the procedure. Surgery was initiated with induction of local anesthesia using an inferior alveolar nerve block and submental extrapharyngeal infiltrations using $2 \%$ Lidocaine Hydrochloride with 1 : 100,000 epinephrine. Surgical access was initiated with an extraoral incision, followed by detachment and dissection of the tissues in planes up to the depth of the periosteum, exposing the mandibular bone base. For ostectomy and crown exposure of the dental element (Figure 3A), we used the spherical drill bit \#08 on a straight part, followed by a dental prosthesis performed with frustoconical drill \#702 with a high rotation to facilitate the removal of the tooth. The crown was removed with a lift and in root sequence (figure $3 \mathrm{~B}$ and $3 \mathrm{C}$ ). The pericoronary hood was removed 
(figure 3D), the borders regularized, and irrigated with a $0.9 \%$ saline solution. We used Monocryl 4-0 sutures for internal planes and nylon 5-0 on the skin. The patient

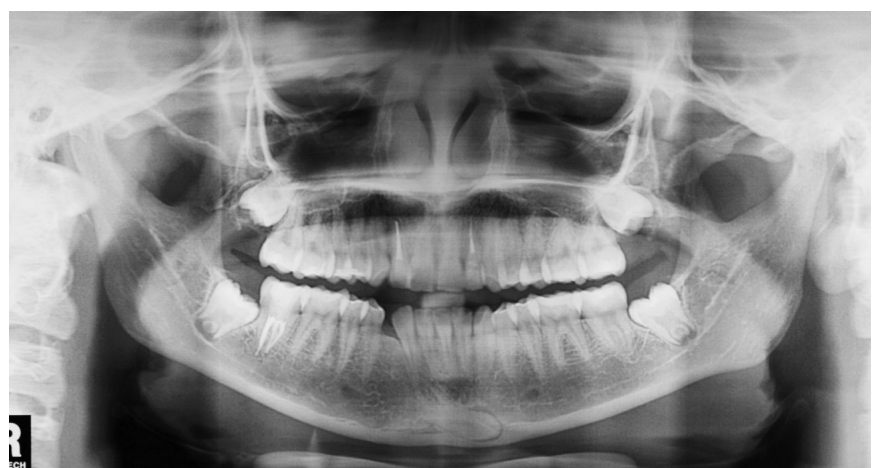

Figure 1. Panoramic radiograph shows element 43 , including crossing of the mandibular midline.

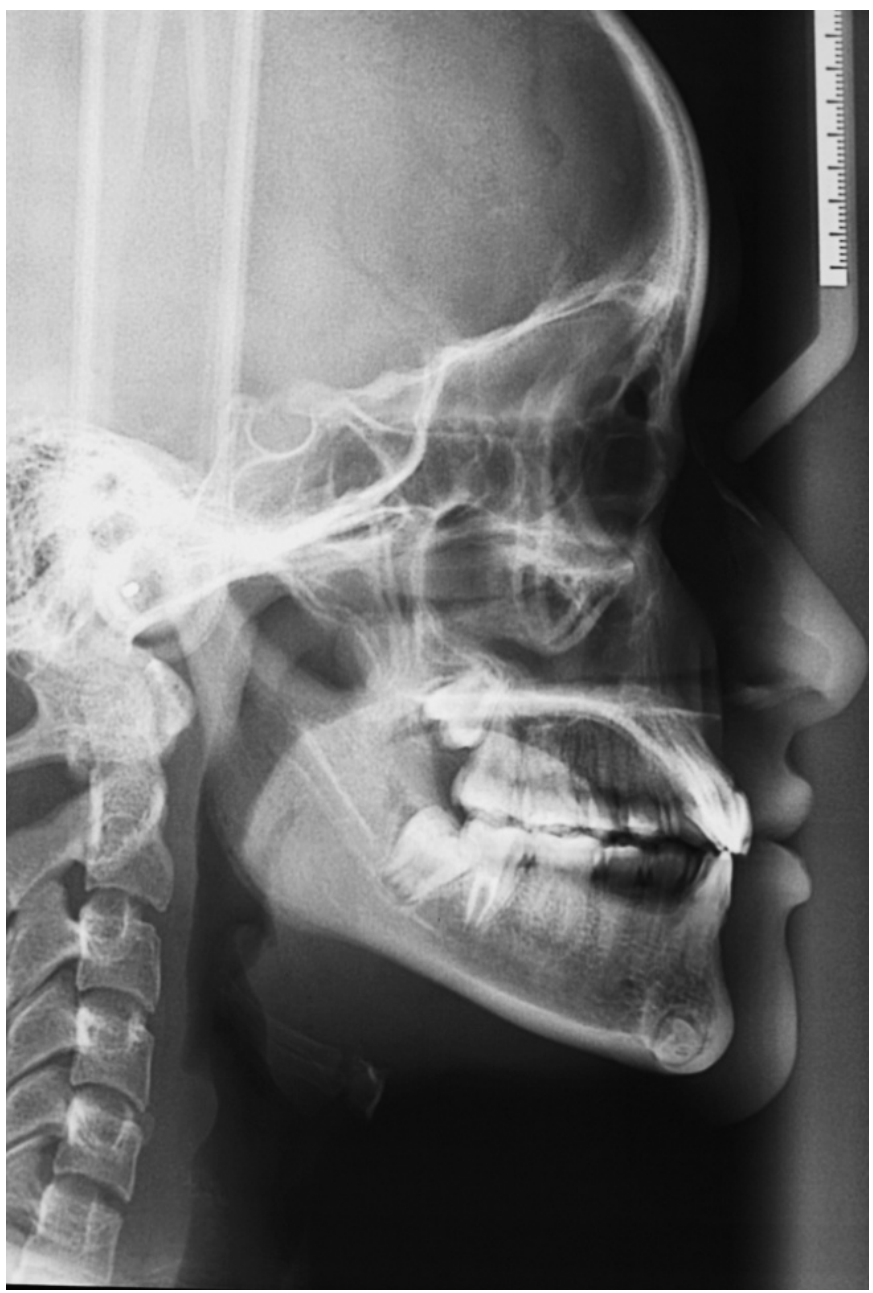

Figure 2. Lateral teleradiography shows the presence of the included dental element 43 located in the mandibular base. was instructed about postoperative care and prescribed the prophylactic antibiotic amoxicillin and codeine and paracetamol for analgesia.

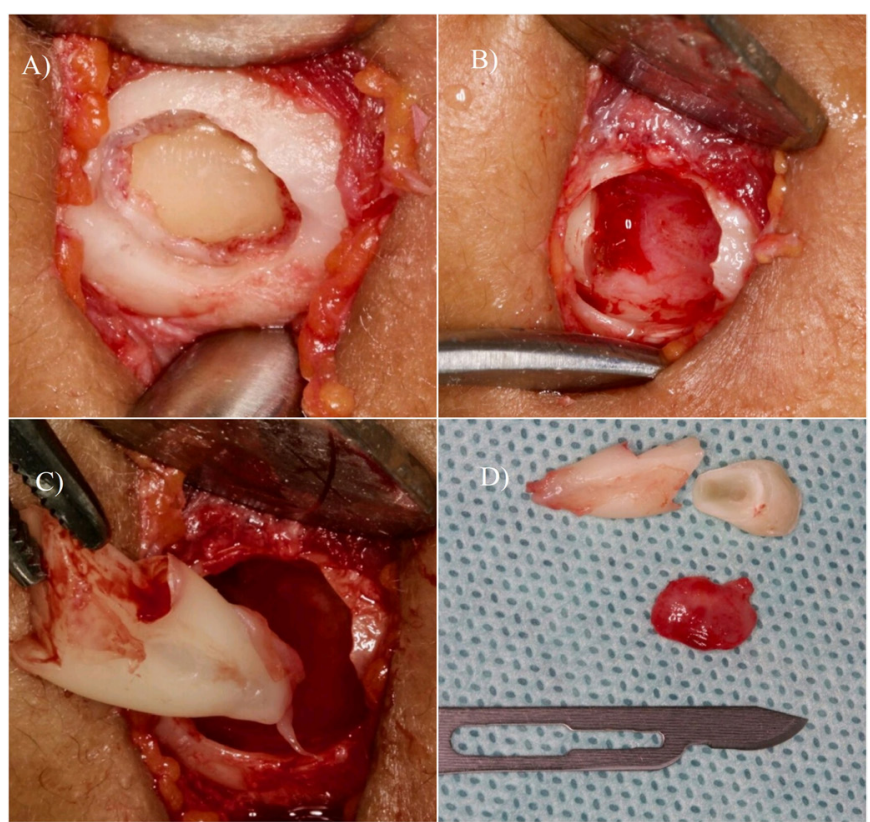

Figure 3. A) Ostectomy and exposure of the crown of the tooth, B) tooth incision to facilitate removal of the tooth, B and C) The crown was removed with a lift in a root sequence, D) Removal of the pericoronary hood.
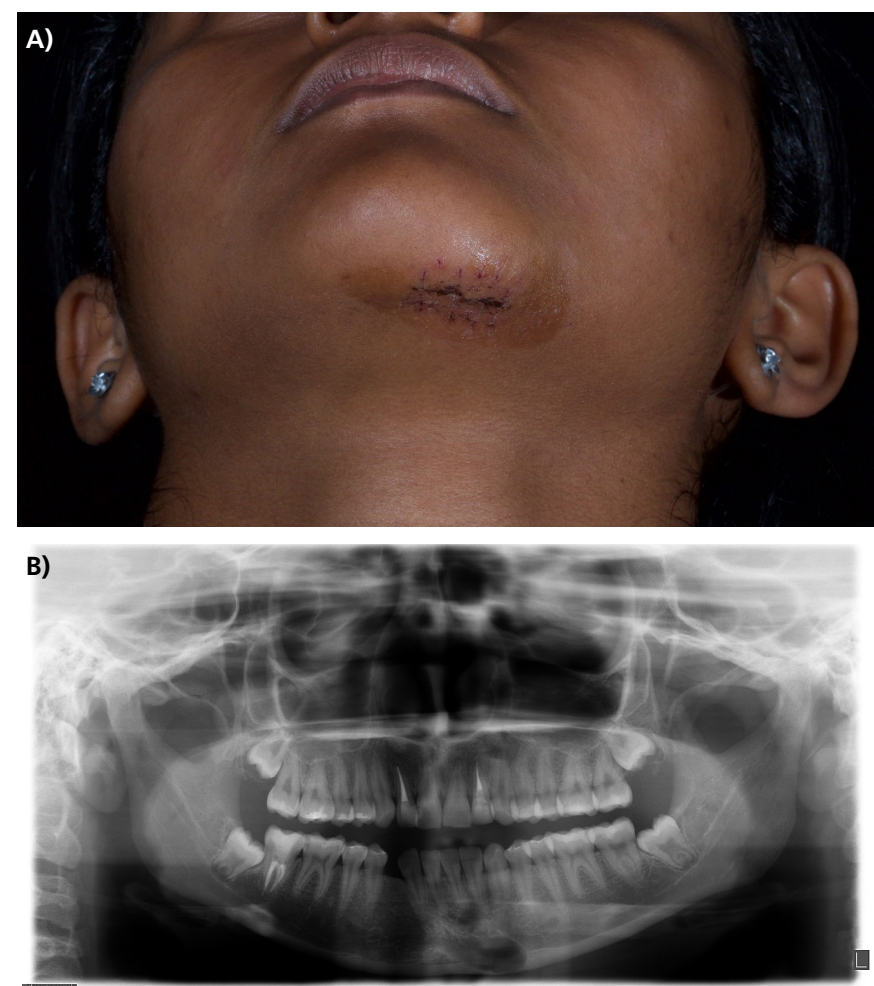

Figure 4. Our patient on postoperative day 7 showing good cicatricial appearance. Panoramic radiography on postoperative day 7 . 
Over the seven-day postoperative period, the patient reported no pain or somatosensory changes. Her postoperative edema was minimal, and the sutures were maintained with good cicatricial appearance and without phlogistic signs. After this, the skin sutures were performed (figure 4A). On panoramic radiography 7 days after surgery, we could visualize a bone shop (figure 4B). The patient remained in follow-up for a period of 2 years, wherein she exhibited a smooth skin line scar (Figure 5A) and bone growth in the surgical shop (figure 5B).
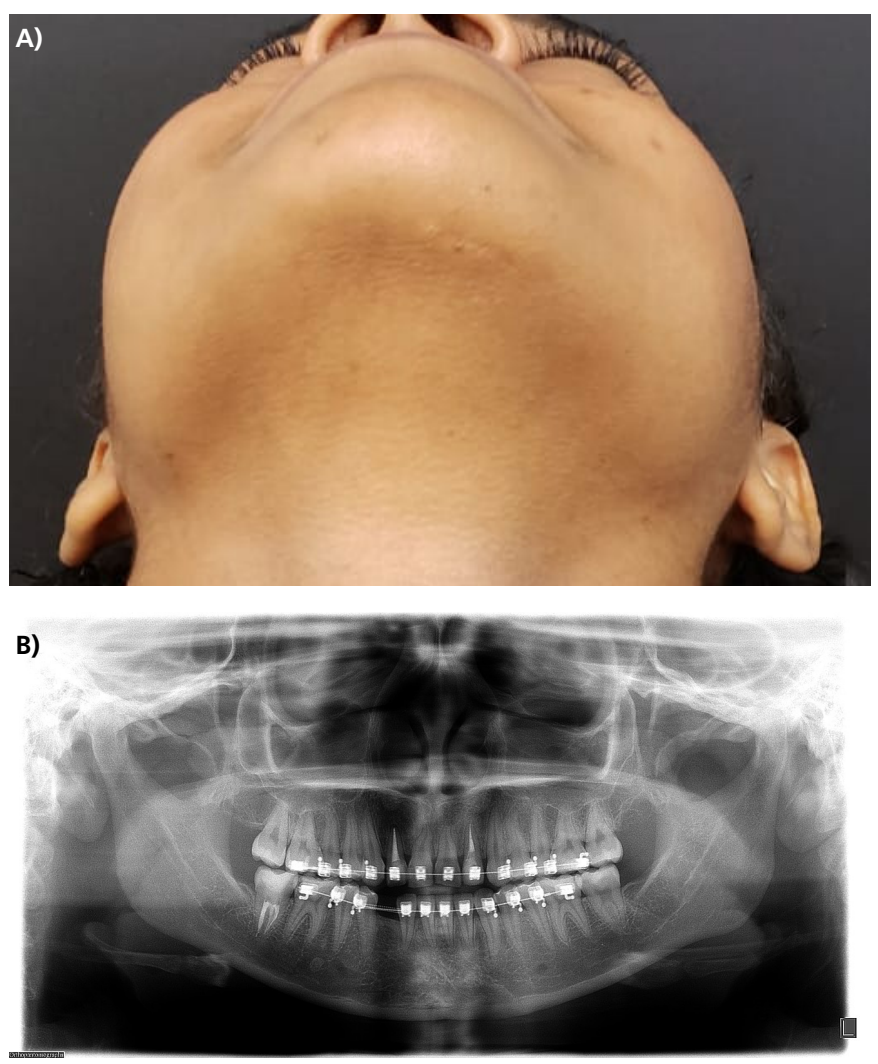

Figure 5. A) Our patient at a 2-year follow-up appointment showing good cicatricial appearance, B) Panoramic radiography after 2 years of control.

\section{DISCUSSION}

Transmigration is a rare dental anomaly that affects only the mandibular canines [12]. Canine migration most frequently occurs in the mesial direction, crossing the mandibular symphysis by lodging on the opposite side of the arcade [10].
Lower impacted canines are less common than impacted third molars, maxillary canines, and mandibular premolars $[13,14]$. The mandibular canines are impacted in approximately $0.1 \%$ of cases [15]. In a retrospective study of 94 impacted lower canines, found transmigration in approximately $40.4 \%$ of impacted lower canines [16]. However, in some cases, they can occur bilaterally [17].

Etiological factors and the various mechanisms of transmigration are poorly understood [18], but include factors such as the absence of a dental arch space [19], supernumerary teeth, loss of primary teeth, hereditary factors, endocrine disorders, trauma [20], cysts, and tumors [21]. Agenesis of the lateral incisor can lead to medialization of deciduous canine teeth; thus, not providing guidance for the eruption of permanent canines [22].

Costello [5] and Joshi [1], reported that mandibular canine transmigration is more common in females, as with our patient. Another investigation reported that transmigrated canines were approximately twice as prevalent in females, compared to males [23]. Another study indicated that the left side canine is more frequently affected than the right-side canine (1.6: 1) [15].

Our cases exhibited a type 2 canine transmigration, as per Mupparapu's classification scheme [7], where the canine appears horizontally and near the lower border of the mandible, below the apex of the incisors. Plakwicz et al. [23], examined 93 patients with transmigrated canines and found that type 2 migrations occurred in $23.7 \%$ of cases. With respect to age, they found that only $25 \%$ occurred in individuals older than 15.5 years [23].

Treatment options for transmigrated lower canines include autogenous transplantation, orthodontic traction, and radiographic observation [3,7,10,24-25]. Impacted teeth can cause external radicular scarring and may damage adjacent teeth; thus, radiographic monitoring is indicated [26]. The great majority of included teeth can be surgically removed, due to the failure potential of other treatment mediums [27], and may be performed using either intra- or extra-buccal access [15].

Intra-buccal access for teeth at the base of the mandible can be complicated by limited spacing, difficult visualization, and ostectomy of a large bone volume [24]. In rare cases, extra-buccal access is used because it provides a better operative field for transmigrated canine removal [24]. In the present study the transmigrated canine was located vestibularly and near the mandibular base, thus indicating 
a more conservative ostectomy in the region. The extraoral approach has several disadvantages including the possibility of nerve damage and aesthetic complaints [28]. In the present study, no motor or somatosensory complications of extra-buccal surgical access were observed.

\section{CONCLUSION}

Canines located near the base of the mandible are rarely discussed in the literature, compared to impacted upper canines due to their relative rarity. Inclusive teeth are usually asymptomatic, and therefore typically identified only during routine radiographic examinations. Our case was treated via surgical removal with extra-buccal exposure due to the impossibility of orthodontic traction. Treatment depends on detailed clinical and radiographic planning, the surgeon's technical-scientific abilities, the age of the patient, and the position of the canines.

\section{Collaborators}

LAP SOUTO, is responsible for the conduct of the case, bibliographic review. D MENESES-SANTOS, for the bibliographic review, CMC RODRIGUES, for the photographs and image formatting. CJ SILVA, for the scientific review of the article. FS ROCHA, by the scientific and critical review of the article. MCP SILVA, chief surgeon responsible for the case and review of the article.

\section{REFERENCES}

1. Joshi MR. Transmigrant mandibular canines: a record of 28 cases and a retrospective review of the literature. Angle Orthodontist. 2001;71(1):12-22. http://dx.doi.org/10.1043/0 003-3219

2. Suméria $P$, Suméria $H$, Ozden $B$, Otan F. Transmigration of mandibular canines: a report of six cases and a review of the literature. J Contemp Dent Pract. 2007; 8(3):104-110.

3. Auluck A, Nagpal A, Setty S, Pai K, Sunny J. Transmigration of impacted mandibular canines: report of four cases. J Can Dent Assoc. 2006;72: 249-52.

4. Alaejos-Algarra C, Berini-Aytes L, Gay-Escoda C. Transmigration of mandibular canines: report of six cases and review of the literature. Quintessence Int. 1998;29(6):395-8.

5. Costello JP, Worth JC, Jones AG. Transmigration of permanent mandibular canines. Br Dent J. 1996;181(6):212-3. http:// dx.doi.org/10.1038/sj.bdj.4809215

6. Okada H, Miyake S, Toyama K, Yamamoto H. Intraosseous tooth migration of impacted mandibular premolar: computed tomography observation of 2 cases of migration into the mandibular neck and the coronoid process. J Oral Maxillofac Surg. 2002;60(6):686-9. http://dx.doi.org/10.1053/joms.200 2.33122

7. Mupparapu M. Patterns of intra-osseous transmigration and ectopic eruption of mandibular canines: review of literature and report of nine additional cases. Dentomaxillofacial Radiol. 2002;31(6):355-60. http://dx.doi.org/10.1038/sj.dmfr. 4600732

8. Bishara SE. Impacted maxillary canines: a review. Am J Orthod Dentofacial Orthop. 1992;101(2):159-171. http://dx.doi. org/10.1016/0889-5406 (92) 70008-X

9. O'Carroll MK. Transmigration of the mandibular right canine with development of odontoma in its place. Oral Surg Oral Med Oral Pathol. 1984;57(3):349. http://dx.doi. org/10.1016/0030-4220(84)90194-4

10. Buyukkurt MC, Aras MH, Caglaroglu H, Gungormus M. Transmigrant mandibular canines. J Oral Maxillofac Surg. 2007;65(10):2025-2029. http://dx.doi.org/10.1016/j.joms.20 06.02 .033

11. Candeiro GTM, Tavares RN. Tratamento cirúrgico em transmigração de canino inferior impactado: relato de caso. Rev Fac Odontol Porto Alegre. 2009;50(3):36-39. http:// dx.doi.org/10.22456/2177-0018.11801

12. Vuchkova J, Farah C. Canine transmigration: comprehensive literature review and report of 4 new Australian cases. Oral Surg Oral Med Oral Pathol Oral Radiol Endod. 2010;109:e46-e53. http://dx.doi.org/10.1016/j.tripleo.2009.12.031

13. Broadway RT. A misplaced mandibular permanent canine. Br Dent J. 1987;163(11):357-8. http://dx.doi.org/10.1038/ sj.bdj.4806308

14. Fiedler LD, Alling CC. Malpositioned mandibular right canine: report of case. Int Oral Surg. 1968; 26(6):405-7.

15. Camilleri S, Scerri E. Transmigration of mandibular canines a review of the literature and a report of five cases. Angle Orthod. 2003;73(6):753-62. http://dx.doi.org/10.1043/00033219(2003)073 <0753:TOMCRO>2.0.CO;2

16. Bertl MH, Frey C, Bertl K, Giannis K, Gahleitner A, Strbac GD. Impacted and transmigrated mandibular canines: an analysis of 3D radiographic imaging data. Clin Oral Investig. 2018; 22(6):2389-2399. http://dx.doi.org/10.1007/s00784-018-23 42-0

17. Silva CJ, Marquez IM, Nascimento FFAO. Transmigração de caninos inferiores. Rev Bras Cir Impl. 2001; 8(30):64-175.

18. Milano M, Barrett L, Marshall E. Extraction of a horizontally impacted mandibular canine through a genioplasty approach: report of a case. J Oral Maxillofacial Surg. 1996;54(10):1240-1242. http://dx.doi.org/10.1016/s0278-2391(96)90360-2

19. Pippi R, Kaitsas R. Mandibular canine transmigration: aethiopathogenetic aspects and six new reported cases. Oral Surg. 2008;1(2):78-83. https://doi.org/10.1111/j.1752-248X. 2008.00014.x

20. Buyukkurt MC, Aras MH, Caglaroglu M. Extraoral removal of a transmigrant mandibular canina associated with a dentigerous cyst. Quintessence Int. 2008;39(9):767-770. 
21. Salamanca C, Ottone NE, Arias RC, Garay I, Fuentes R. Caninos Transmigrados associados a odontomas. Int J Morphol. 2017; 35(2):465-468. https://doi.org/10.4067/S071 7-95022017000200013

22. Tarsariva VM, Javam C, Parmar YS, Bandlapali A. Unusual intrabony transmigration of mandibular canine: case series (reporto f 4 cases). BMJ Case Rep. 2015;bcr2014205398. https://doi.org/10.1136/bcr-2014-205398

23. Plakwicz P, Abramczk J, Woitaszek-Lis J, Saikowska J, Warych B, Gwron K, et al. The retrospective study of 93 patients with transmigration of mandibular canine and a comparative analysis with a control group. Eur J Orthod. 2019;41(4):390-396. doi: 10.1093/ejo/cjy067

24. Alberto PL. Management of the impacted canine and second molar. Oral Maxillofac Surg Clin North Am. 2007;19(1):59-68. https://doi.org/10.1016/j.coms.2006.11.001

25. Koszowski R, Pisulska-Otremba A, Wóicik S, SmieszekWilczewska J. Canine transmigration accompanying mandibular retrognathism secondary to osteitis. Open Med. 2015;10(1):566-571. https://doi.org/10.1515/med-2015-0096

26. Cavuoti S, Matarese G, Isola G, Abdolreza J, Femiano F, Perillo L. Combined orthodontic-surgical managemente of a transmigrated mandibular canina. Angle Orthod. 2016;86(4):681-91. https://doi.org/10.2319/050615-309.1

27. Filho J, França S, Araújo L, Pereira J, Belchior I, Sampieri M. Intervenção cirúrgica de um canino incluso em sínfise mandibular: relato de caso. Rev Facul Odontol UPF. 2018;23(3):329-332.

28. Bali A. Bali D, Iver N, Sharma A. Extraoral enucleation of dentigerous cyst: A case report of rare treatment option and review of literatures. Indian J Oral Sci. 2012;3:53.

Received on: $3 / 3 / 2019$ Approved on: 26/6/2019 